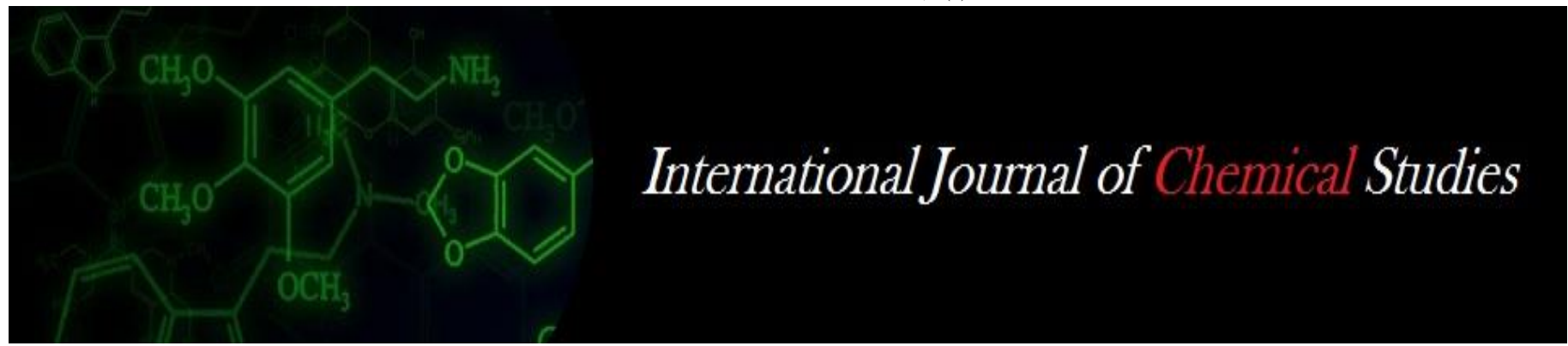

P-ISSN: 2349-8528

E-ISSN: 2321-4902

www.chemijournal.com

IJCS 2020; 8(6): 776-779

(C) 2020 IJCS

Received: 20-09-2020

Accepted: 28-10-2020

Yogesh

Department of Agronomy,

School of Agriculture, Lovely

Professional University,

Phagwara, Punjab, India

Vinit Sharma

Department of Vegetable

Science, School of Agriculture,

Lovely Professional University,

Phagwara, Punjab, India

Sarvjeet Kukreja

Department of Agronomy,

School of Agriculture, Lovely

Professional University,

Phagwara, Punjab, India

\section{Conservation agriculture for combating climate change and sustainable agriculture: A review}

\author{
Yogesh, Vinit Sharma and Sarvjeet Kukreja
}

DOI: https://doi.org/10.22271/chemi.2020.v8.i6k.10864

\begin{abstract}
Conservation agriculture (CA) is a practice in which soil is kept nearly undisturbed by adopting the techniques like zero tillage or minimum tillage, soil mulch, crop rotation, in-situ crop residue management etc. CA is in practice from the last two decades in India, though there are some constraints in its adoption. In Indo-Gangetic plains, wheat- rice based cropping system is very common and generally more tillage operations are applied to the soil. But, now the concept of CA is gaining popularity and no-till or minimum tillage practices are being adopted at a significant level. The main aim of CA is to decrease the input and increase the output in terms of crop yield as well as reduction in the production cost. CA technology is also environmental friendly as it promotes the efficient and precise use of resources in a sustainable manner. There are various constraints which limit the adoption of CA technology in India like poor availability of modern implements, continuously decreasing land holding size, unavailability of finance and lack of awareness in small and marginal farmers etc. So, from the sustainability point of view, there is an urgent need to make strategies to promote CA through the development of new policies beneficial for the farmers. This article reviews the various aspects of conservation agriculture in the Indian context.
\end{abstract}

Keywords: Conservation agriculture, resource use efficiency, zero tillage, sustainability

\section{Introduction}

Worlds' population is anticipated to reach approximately 9.7 billion by 2050 . To feed such a huge population, food production must be increased in the near future. But the present day situations are challenging for the farming community as the resources required for cultivation of crops i.e. arable land and good quality water is limited in amount. Moreover, the climate is changing at a faster speed and the frequency of extreme weather events like drought, flood and temperature have increased significantly in the past decades. Therefore, we require newer and sustainable agricultural systems to meet the requirements of people.

In the current scenario due to the increase in cost of input in agricultural systems, changing of climate, depleting of natural resources, increase in population and poverty it is very challenging for most of the Asian countries to attain the food security. Some other challenging factors viz. soil erosion, salinization and decrease in soil organic matter also leads to nonsustainability. Eliminating non-sustainable part of conventional agriculture viz. Tillage practices, ploughing, monoculture, removing organic matter from the soil is very critical for future sustainability. Therefore, to maintain the balance between demand and supply as well as to attain sustainability, Conservation agriculture is practiced. CA at present has increased to 8 percent of world's arable land.

$\mathrm{CA}$ is a practice in which soil disturbance is made negligible by adopting the concept of zero tillage or minimum tillage, soil mulch, rotation of crop, avoiding burning of paddy straw in the field (Pradhan et al., 2017) ${ }^{[23]}$.

Main aim of CA is to maintain the yield and profit to attain a balance between agriculture, environment and economics. It promotes both the economic and social benefits by decreasing the costs of input and labour and at the same time it conserves the environment. By CA, farmers provide healthier environment to the larger community by reducing the use of pesticides, herbicides, fossil fuels, machinery and other soil and water pollutants to maintain the environmental integrity.

As per FAO definition, conservation agriculture is to1) attain high profit, 2) sustainable production levels, and 3) to protect the environment.
Corresponding Author: Sarvjeet Kukreja

Department of Agronomy,

School of Agriculture, Lovely

Professional University,

Phagwara, Punjab, India 
CA is better alternative of conventional agriculture practices which includes burning of crop residues, intensive agriculture and use of pesticides (Table 1). CA is mainly based on improving and conserving natural resources more efficiently. It can only be achieved when there is sustainable or integrated management of water, soil and biological resources.

Table 1: Distinguishing features of Traditional tillage (TT), Conversation tillage (CT) and Conservation agriculture (CA) (Partially adopted from Hobbs et al., 2007) ${ }^{[13]}$

\begin{tabular}{|c|c|c|c|}
\hline $\begin{array}{c}\text { Sr. } \\
\text { No. }\end{array}$ & Traditional Tillage (TT) & Conservation tillage (CT) & Conservation agriculture (CA) \\
\hline 1. & High Soil disturbance & $\begin{array}{c}\text { Lower soil disturbance } \\
\text { compared to TT }\end{array}$ & Zero or minimal tillage and surface is covered \\
\hline 2. & High wind and soil erosion & $\begin{array}{c}\text { Wind and soil erosion is } \\
\text { low as compared to TT }\end{array}$ & Wind and soil erosion is negligible \\
\hline 3. & Biological processes are destroyed & $\begin{array}{c}\text { Reduce compaction in the } \\
\text { soil }\end{array}$ & Use of mulch and it is best of all the three practices \\
\hline 4. & Soil biological health poor & $\begin{array}{c}\text { Moderate soil biological } \\
\text { health }\end{array}$ & High soil biological health \\
\hline 5 & Poor water infiltration & Water infiltration is good & Soil organic matter highest \\
\hline 6. & Soil organic matter lost due to high tillage & $\begin{array}{c}\text { Soil organic matter remain } \\
\text { but lesser than CA }\end{array}$ & $\begin{array}{c}\text { Reduces the weed } \\
\text { population }\end{array}$ \\
\hline 7. & $\begin{array}{c}\text { Weeds are controlled but more weed seeds will } \\
\text { germinate due to dispersal through air or } \\
\text { machines }\end{array}$ & $\begin{array}{c}\text { In the initial phase weed population is high but due to laying } \\
\text { down of crop residues in the field will suppress the weed } \\
\text { population }\end{array}$ \\
\hline 8. & Variability in surface soil temperature & $\begin{array}{c}\text { Intermediate surface soil } \\
\text { temperature }\end{array}$ & Highest surface soil temperature \\
\hline 9. & Highest consumption of diesel & $\begin{array}{c}\text { Consumption of diesel is } \\
\text { moderate }\end{array}$ & Much reduced consumption of diesel as compared to all \\
\hline 10. & Yield is good & Same yield as TT & Same yield as TT but if planting done on time it can be higher \\
\hline
\end{tabular}

\subsection{Status of conservation agriculture worldwide}

Conservation agriculture is now practiced in 125Mha (FAO 2012) ${ }^{[6]}$. Majorly it is practiced in USA, Brazil, Argentina and Australia which is about $75.5 \%$ of the global area. In India, CA is practiced on about $1.5 \mathrm{Mha}$ (Jat et al., $2012^{[17]}$; www.fao.org/ag/ca/6c.html). Moreover, in the Indo- Gangetic plains a latest technology is introduced in Rice-Wheat cropping system viz. zero till (ZT) as conventional agriculture is gradually changing to $\mathrm{CA}$ i.e. from intensive tillage to zero tillage. CA is now practiced in other cropping systems also to enhance the sustainability in agriculture. To change the RW system, new cropping pattern or systems are introduced i.e. relay cropping of sugarcane and pulses, intercropping of wheat and mustard. Combining of all resources conservation technology i.e. cropping, livestock, land and water use management will further enhance the sustainability.

$\mathrm{CA}$ is being promoted from last 8 to 10 years and now it is being widely adopted by the farmers of India. ICAR and State agriculture universities are being instrumental in developing and spreading of conservation agriculture. Zero- till- seedcum fertilizer is rapidly dominating now-a-days in rice-wheat cropping system. Some other CA systems including raised bed planting system, laser leveller and residue management practices. In India there is approximately $25-30 \%$ increase in zero-till-drill in wheat crop (Sangar et al., 2005) ${ }^{[26]}$. Laser leveller and raised bed planting technologies are also used in North West region of India.

Some other countries where CA is being practiced now a day are Canada (13.5Mha), Russian Federation (4.5Mha), China (4.1Mha), Paraguay (2.4Mha) and Kazakhstan (1.6Mha) $\left(\right.$ FAO, 2012) ${ }^{[6]}$.

\section{Principle of Conservation Agriculture}

CA is now practiced in most of the part of the world and its main principle is to make the land suitable for production in future (Wassmann, 2009; Behera et al. 2010; Lal, 2013) [33, 2, 19]. Today adoption of conservation agriculture is very necessary to enhance the crop productivity by conserving the natural resources to make the agriculture more sustainable. There are 3 main principles on which CA depends (Bhan and Behera, 2014). These are:

\subsection{Minimal soil disturbance}

Least or minimum soil disturbance means that we are practicing minimal or zero tillage in the field. It improves the biological and physical properties of the soil which helps in improving the soil structure. Uses of heavy mechanical tillage practices are known to reduce the organic matter content in the soil and thereby increase the chances of re-germination of weeds (Kassam and Friedrich, 2009) ${ }^{[18]}$.

\subsection{Soil cover}

Soil mulch aims to reduce the weed population or completely eliminate the weeds by cutting off the light. Permanent soil mulch also prevents soil from the direct contact of sun and rain and sequentially improves the soil's biological activity in the soil (Ghosh et al., 2010) ${ }^{[9]}$.

\subsection{Crop rotation}

Every crop has its own mechanism and response w.r.t. effect on the quantity and quality of inputs provided viz. water extraction rate, nutrient use (Huggins et al., 2007) ${ }^{[14]}$. Substitution of monoculture with crop rotation in the field increases the deposition of residues in the soil organic carbon content (SOC) (Huggins et al., 2007; Santos et al., 2011; Concericao et al., 2013) [14, 27, 3]. Legume crops contain sufficient amount of $\mathrm{N}$ which is responsible for increasing the soil fertility as well as biomass production of the crop (Hansen et al., 2012; Mbuthia et al., 2015; Raphael et al., 2016; Veloso et al., 2018) ${ }^{[12.21,24,30]}$. Residue cover on the soil also reduces the soil erosion, pests, weeds, diseases and nutrient leaching in the field (Tittonell et al., 2012; Gabriel et al., 2013; Veloso et al., 2018; Williams et al., 2018) [29, 7, 24, 34].

Crop rotation is necessary to provide diverse nutrition to the soil microbes and it also helps in replenishment of nutrients in 
the soil which has been lost by leaching. It has been reported to decrease the pest population through biological nitrogen fixation and increasing biodiversity (Dumanski et al., 2006) [4].

\section{Benefits and Constraints of Conservation Agriculture:}

There are various agronomical, economic and environmental benefits of CA which will increase the awareness and attraction amongst the farmers to implement CA practice on agricultural land. These benefits are listed below:

1. It increases the production and productivity of crop.

2. Increases the profitability of the farmers by the use of natural resources efficiently.

3. Conserves the environment and make the agriculture more suitable for future generations.

4. It increases soil organic carbon content and reduces global warming in the environment.

5. Saves energy (60-90\%), time and reduces the production cost by (15-16\%) thereby increases farm income.

6. Improves different physical, chemical and biological properties thereby increases crop production and productivity by improving soil quality (Jat et al., 2009a; Gathala et al., 2011) ${ }^{[15,8]}$.

7. Increases efficiency of nutrient and water availability (Jat et al., 2012; Saharawat et al., 2012) ${ }^{[17,25]}$

8. Output is more and input is low hence profitability is higher. This is achieved by utilizing the natural resources efficiently.

9. Decreases incidence of weed population viz. Phalaris Minor in wheat crop (Malik et al., 2005) ${ }^{[20] .}$

10. Use of mulching technology to reduce surface evaporation and weed population on one hand and to increase the biological activity on the other hand. (Jat et al., 2009b; Gathala et al., 2011) ${ }^{[16,8]}$.

11. By adoption of zero tillage farmers will be able to save 50-60 litres of diesel per hectare in the Indo-Gangetic plains (Sharma et al., 2005) ${ }^{[28]}$.

\subsection{Demerits of Conservation Agriculture}

Mentality of the farmers who are more influenced to intensive agriculture is the major constraint of CA.

Without fertilizers and tillage there can be immobility of nutrients which will leads to reduction in yield (Giller et al., $2009)^{[10]}$. By the decomposition of crop residues, in the field the amount of $\mathrm{C}$ : $\mathrm{N}$ ratio will increase which may lead to $\mathrm{N}$ immobilization due to increase in biological activity (Verhulst et al., 2010) ${ }^{[31]}$. Weed pressure will also be increased by the use of minimal tillage practices (Baudron et al., 2007) ${ }^{[1]}$. If the weed population is high it can be controlled either by the use of herbicides or manually by hand weeding so increase the labour cost (Baudron et al., 2007) ${ }^{[1]}$. Roots of perennial weeds are deeper so they can only be removed by the use of herbicides (Vogel, 1995) ${ }^{[32]}$.

Further, there is shortage of hybrid legume seeds in the market and also there is shortage of market for the leguminous crop (Baudron et al., 2007; Haggblade \& Tembo, 2003) ${ }^{[1,11]}$. Farmers are not much aware about the legume crops in the planting system because of the spacing. (Baudron et al., 2007) ${ }^{[1]}$.

In an experiment of crop rotation of maize, sun hemp and cotton, it is analyzed that maximum profit is in the maize crop (Thierfelder \& Cheesman, 2011) ${ }^{[35]}$ despite yield increases from rotation. Due to mulching practice there can be infestation of termites (Nyathi et al., 2011) ${ }^{[22] .}$

\section{Conclusion}

Conservation agriculture is the latest technology. Its main aim is to reduce the practices of intensive tillage to achieve sustainability in agriculture. A shift to CA has become very necessary not only to conserve the resources but also to conserve the environment. Conservation agriculture reduces the costs of input, cultivation and wise use of field resources to maintain sustainability. It is very necessary to make the farmers more aware about CA and it can be done only when there is awareness among the people and a change can be brought in the mindset of the farmers using traditional tillage through educational programmes by demonstrating them the benefits of conservation agriculture.

\section{References}

1. Baudron F, Mwanza HM, Triomphe B, Bwalya M. Conservation agriculture in Zambia: A case study of Southern Province. Nairobi: African Conservation Tillage Network, Centre de Cooperation Internationale de Recherché Agronomique pour le Dévelopment, Food and Agricultural Organization of the United Nations, 2007.

2. Behera UK, Amgain LP, Sharma AR. Conservation agriculture: principles, practices and environmental benefits. In: Behera, U.K., Das, T.K. and Sharma, A.R. (Eds.), Conservation Agriculture. Indian Agricultural Research Institute, New Delhi, 2010, 28-41.

3. Conceicao PC, Dieckow J, Bayer C. Combined role of no-tillage and cropping systems in soil carbon stocks and stabilization. Soil and Tillage Research. 2013; 129:40-47. Doi: 10.1016/j.still.2013.01.006

4. Dumanski J, Peiretti R, Benetis J, McGarry D, Pieri C. The paradigm of conservation tillage. Proceedings of World Association of Soil and Water Conservation, P1, 2006, 58-64.

5. Food and Agriculture Organization of the United Nations (FAO). Conservation Agriculture, 2009. http://www.fao.org/ag/ca

6. Food and Agriculture Organization of the United Nations (FAO), 2012, Available online at http://www.fao.org/ag/ca/6c.html.

7. Gabriel JL, Garrido A, Quemada M. Cover crops effect on farm benefits and nitrate leaching: Linking economic and environmental analysis. Agricultural Systems. 2013; 121:23-32. Doi: 10.1016/j.agsy.2013.06.004

8. Gathala MK, Ladha JK, Saharawat YS, Kumar V, Sharma PK. Effect of Tillage and Crop Establishment Methods on Physical Properties of a Medium-Textured Soil under a Seven-Year Rice - Wheat Rotation. Soil Science Society of America Journal. 2011; 75:18511862.

9. Ghosh PK, Das A, Saha R, Kharkrang E, Tripathy AK, Munda GC et al. Conservation agriculture towards achieving food security in north east India. Current Science. 2010; 99(7):915-921.

10. Giller KE, Witter E, Corbeels M, Tittonell P. Conservation agriculture and smallholder farming in Africa: The heretics' view. Field Crops Research. 2009; 114:23-24.

11. Haggblade S, Tembo G. Development, diffusion and impact of conservation farming in Zambia. Food Security Research Project. Lusaka, Zambia: Michigan State University, 2003. Retrieved from: http://aec.msu.edu/fs2/zambia/wp8zambia.pdf

12. Hansen NC, Allen BL, Baumhardt RL, Lyon, DJ. Research achievements and adoption of no-till, dry land 
cropping in the semi-arid U.S. Great Plains. Field Crops Research. 2012; 132:196-203. Doi: 10.1016/j.fcr.2012.02.021

13. Hobbs PR. Conservation agriculture: what is it and why is it important for future sustainable food production. Journal of Agricultural Science. 2007; 145(2):127-137.

14. Huggins DR, Allmaras RR, Clapp CE, Lamb JA, Randall GW. Corn- Soybean Sequence and Tillage Effects on Soil Carbon Dynamics and Storage. Soil Science Society of America Journal. 2007; 71:145-154. Doi: 10.2136/sssaj2005.0231

15. Jat ML, Gathala MK, Ladha JK, Saharawat YS, Jat AS, Kumar V. Evaluation of Precision Land Levelling and Double Zero-Till Systems in Rice-Wheat Rotation: Water use, Productivity, Profitability and Soil Physical Properties. Soil and Tillage Research. 2009a; 105:112121.

16. Jat ML, Singh RG, Saharawat YS, Gathala MK, Kumar $\mathrm{V}$, Sidhu HS. Innovations through conservation agriculture: progress and prospects of participatory approach in the Indo-Gangetic plains. In Pub Lead Papers, 4th World Congress on Conservation Agriculture, New Delhi, India, 2009b, 60-64.

17. Jat ML, Malik RK, Saharawat YS, Gupta R, Bhag M, Paroda R. Proceedings of Regional Dialogue on Conservation Agricultural in South Asia, New Delhi, India, APAARI, CIMMYT, ICAR, 2012, 32.

18. Kassam AH, Friedrich T. Perspectives on Nutrient Management in Conservation Agriculture. Invited paper, IV World Congress on Conservation Agriculture, New Delhi, India, 2009.

19. Lal R. Climate-resilient agriculture and soil Organic Carbon. Indian Journal of Agronomy. 2013; 58(4):440450.

20. Malik RK, Gupta RK, Singh CM, Yadav A, Brar SS, Thakur TC. Accelerating the Adoption of Resource Conservation Technologies in Rice Wheat System of the Indo-Gangetic Plains. Proceedings of Project Workshop, Directorate of Extension Education, Chaudhary Charan Singh Haryana Agricultural University (CCSHAU), Hisar, India, 2005.

21. Mbuthia LW, Acosta-Martínez V, DeBruyn J, Schaeffer S, Tyler D, Odoi E. Long term tillage, cover crop, and fertilization effects on microbial community structure, activity: Implications for soil quality. Soil Biology and Biochemistry. 2015; 89:24-34. Doi: 10.1016/j.soilbio.2015.06.016

22. Nyathi P, Mazvimavi K, Kunzekweguta M, Murendo C, Masvaya E, Tirivavi R. Assessing the feasibility of mulching in mixed-crop livestock systems in Zimbabwe. Presented at: Conservation agriculture regional symposium for southern Africa, Johannesburg, South Africa, 2011.

23. Pradhan P, Verma A, Kumar M. Need of Conservation Agriculture in India: Sustainability. Int. J. Curr. Microbiol. App. Sci. 2018; 7(1):308-314. doi: https://doi.org/10.20546/ijcmas.2018.701.033

24. Raphael JPA, Calonego JC, Milori DMBP, Rosolem CA. Soil organic matter in crop rotations under no-till. Soil and Tillage Research, 2016; 155:45-53. Doi: 10.1016/j.still.2015.07.020

25. Saharawat YS, Ladha JK, Pathak H, Gathala M, Chaudhary N, Jat ML. Simulation of resource-conserving technologies on productivity, income and greenhouse gas emission in rice-wheat system. Journal of Soil Science and Environmental Management. 2012; 3(1):9-22.

26. Sangar S, Abrol JP, Gupta RK. Conservation Agriculture: Conserving Resources Enhancing Productivity, 2005, 19.

27. Santos NZ, Dieckow J, Bayer C, Molin R, Favaretto N, Pauletti V. Forages, cover crops and related shoot and root additions in no till rotations to $\mathrm{C}$ sequestration in a subtropical Ferralsol. Soil and Tillage Research. 2011; 111:208-218. Doi: 10.1016/j.still.2010.10.006

28. Sharma AR, Singh R, Dhyani SK. Conservation tillage and mulching for optimizing productivity in maize-wheat cropping system in the outer western Himalaya region - a review. Indian Journal Soil Conservation. 2005; 33(1):35-41.

29. Tittonell P, Scopel E, Andrieu N, Posthumus H, Mapfumo P, Corbeels M. Agro-ecology-based aggradation-conservation agriculture (ABACO): Targeting innovations to combat soil degradation and food insecurity in semi-arid Africa. Field Crops Research. 2012; 132:168-174. Doi: 10.1016/j.fcr.2011.1 2.011

30. Veloso MG, Angers DA, Tiecher T, Giacomini S, Dieckow J, Bayer C. High carbon storage in a previously degraded subtropical soil under no-tillage with legume cover crops. Agriculture, Ecosystems and Environment. 2018; 268:15-23. Doi: 10.1016/j.agee.2018.08.024

31. Verhulst N, Govaerts B, Verachtert E, Castellanos Navarrete A, Mezzalama M, Wall P. Conservation agriculture, improving soil quality in sustainable production systems. In: Lal, R. and Stewart, B. (Eds.), Food Security and Soil Quality. Boca Raton, FL: CRC Press, 2010.

32. Vogel H. The need for integrated weed management systems in small holder conservation farming in Zimbabwe. Der Tropenlandwirt. 1995; 96:35-56.

33. Wassmann R, Jagadish SVK, Sumfleth K, Pathak H, Howell G, Ismail A et al. Regional vulnerability of climate change impacts on Asian rice production and scope for adaptation. Advances in Agronomy. 2009; 102:91-133.

34. Williams A, Jordan NR, Smith RG, Hunter MC, Kammerer M, Kane DA. A regionally-adapted implementation of conservation agriculture delivers rapid improvements to soil properties associated with crop yield stability. Scientific Reports. 2018; 8:8467. Doi: 10.1038/s41598-018-26896-2

35. Thierfelder C, Cheesman S. Benefits and challenges of crop rotations in maize-based conservation agriculture (CA) cropping systems of southern Africa. Presented at: Conservation agriculture regional symposium for southern Africa, Johannesburg, South Africa, 2011, Abstract available from: http://ecoport.org/ep?SearchType=reference $\&$ Keyword= CASympJhb\&domainId=2\&KeywordWild=BW\&MaxLi $\mathrm{st}=0$ 